\title{
クライエントの主体的な健康行動目標の設定および実施に 向けた参加型カウンセリングプログラムの開発
}

\author{
$\bigcirc$ 岡村祐一 ${ }^{1,3}$ ・ 岡田栄作 ${ }^{2, \#}$ ・佐藤航 ${ }^{3, \#}$ \\ ( ${ }^{1}$ 筑波大学大学院人間総合科学研究科・ ${ }^{2}$ 浜松医科大学健康社会医学講座・ ${ }^{3}$ S\&S Dialogue) \\ キーワード : 参加型カウンセリングプログラム, 行動変容, 健康支援
}

Development of a participatory counseling program for client-oriented target settings and implementation regarding health behavior.

( ${ }^{1}$ Graduate School of Comprehensive Human Sciences, Tsukuba Univ.,

${ }^{2}$ Department of Community Health and Preventive Medicine Hamamatsu University School of medicine., ${ }^{3}$ S\&S Dialogue)

Key Words: Participatory Counseling Program, Behavior Change, Health Promotion

\section{目的}

クライエント (以下 $\mathrm{Cl}$ ) が，何かしらの問題や課題を解決成 長や変容をするためには, 自ら行動しなければならない。そ のためには，クライエント自身が望んでいる，より良い状態 や，望ましい自分自身についてのイメージを持つことが求め られる。

ソリューション・フォーカスト・ブリーフセラピー (solut ion-focused brief therapy:SFBT) とは, Cl のできている点 や強み, 未来という「解決」に焦点を当て, Cl とセラピスト が協働して, 解決構築を目指寸心理療法である (berg, 1994; De John\& Berg, 2013)。特に Cl の健康行動の実施を目的とす る場合，長期的な治療を行うことは離脱者が多いため困難で あるが，SFBT は短期的な治療を指向しているため，健康支援 に適したアプローチであると考えられる。

しかし，健康支援を目的として、SFBT を用いた面接技法は まだ手探りであり, 効果的な面接技法の開発が求められてい る。

本研究は, クライエントが発した言葉を可視化していきな がら, クライエントが自ら健康行動の目標を定め, その健康 行動を主体的に行うことができるカウンセリングプログラム の開発を目的とする。また睡眠をテーマとする $\mathrm{Cl}$ に面接を実 施し，その面接経過を報告する。

\section{方 法}

Cl は，睡眠改善をテーマとする女子大学生 1 名 (A さん)を 対象とした。倫理的配慮として, カウンセリング前に本人に 同意書を得て，個人が特定されないようにした。

初回面接前 課題に対しての意識を尋ねるためにvisual ana log scale (VAS 法)を用いて, 課題に取り組みたい意欲, 問題 の重要性、行動変容ステージについて回答してもらった。

インテーク面接 初回は, どのような健康問題があるのかを Cl から尋ねる。 $\mathrm{Cl}$ が, 抱える課題や悩みを丁寧に聴きながら, 本人の意欲を高めたり，これまでに行ってきた行動に対して 労いの言葉かけや自信づけたりすることで、C1 の強みを発見 する。その中からこの 1 か月間かけて取り組みたいことをテ 一マにする。

面接（2回目）岡村・岡田・津田（2017）が作成したポジ ティブ行動変容カウンセリングのプログラム開発をもとに進 めた。理想・過去や現在の事例・追加アイデア・実行策 4 つ の流れに従って, 半構造化面接を行った。変わるとどんない いことがあるのかを話を広げたり深めたりしながらブレイン ストーミングを行い, クライエントが話したことを $25 \times 75 \mathrm{~mm}$ の付箋に書いて貼った。そのためにこれまでどんなことをし てきたかについて, クライエントに思い出してもらいながら， $12.5 \times 75 \mathrm{~mm}$ の桃色の付嘎に書いて貼った。理想を $100 \%$ とした
時に, 今どの程度到達しているのか数值化する。さらにでき ることをクライエントと一緒に, 実現可能性は考慮せずにア イデアを沢山出していき, $12.5 \times 75 \mathrm{~mm}$ の黄色の付箋に書いて 貼った。その後, マスキングテープで 2 軸を作り（取り掛か りにくい一取り掛かりやすい, モチベーションがない一モチ ベーションが高い), 桃色と黄色の付箋をクライエントに自由 にマッピングしてもらい, 取り掛かりやすくモチベーション が高いものを 1 〜 選び，行動目標を明確にしてから， 25 $\times 75 \mathrm{~mm}$ の付箋に書いて貼った。最後に, その行動がどの程度 実行可能性があるのか数值化した。実行可能性が低い場合は, 行動をできるように, 実行可能性が高まる行動を選び直した。 それをスマホなどで写真に撮ってもらい, 行動前にその写真 を見てもらう。本人の宿題として次回面接までに取り掛かっ てもらった。

面接 $(3$ 回目〜 4 回目 $) 2$ 回目の面接から, どのような行 動をして, その結果どのような状態になったかを尋ねた。行 動の中で上手くいっていることは続け, うまくいかなかった ことは, 再度リソースを探し, 次回の課題とした。

\section{結 果}

就寝前が一番落ち着く時間であり, 友人からのメッセージ などが溜まっていると連絡を返さないといけないと強く思っ てしまう。また，次の日のスケジュールや何をするのかを考 えると, なかなか寝付けないことを話されたため, Aさんの テーマを，「就寝前に気になることを減らす」こととした。2 回目の面接時に, 本人は「ベッドに入る前に友人などへの連 絡をし, 手帳でスケジュールを確認しておくこと」, また, 「荷 物が近くにあると気になってしまうため, 次の日の荷物を準 備して玄関に置いておく」ことを行動目標とし取り掛かるこ ととした。3，4回目時にその行動が上手くいっていたため, 同様の行動を続けた。4 回目で $\mathrm{Cl}$ から就寝時に気になること が減ってきたこと, また行動が習慣化してきており, 目標達 成とポジティブに捉えることができたと話されたため, 面接 を終了とした。

\section{考 察}

Aさんは, 取り掛かることが困難でない行動を自ら選択し， その行動を毎日続けていた。カウンセリングは SFBT の 3 つの 中央哲学を重要視し, 面接を続けることで, 本人の行動を習 慣化することができたと考えられる。健康についてのテーマ を設定する場合には，その問題についてのアセスメントが大 切であり, 本人にヒアリングしながら, 適宜質問紙や生理学 的評価をしていくことが望まれる。今後の課題として, より 多くのカウンセリングを行って, 実証していくこと, またカ ウンセリングプログラムをマニュアル化することである。 